\title{
Mucin clots from microgram amounts of hyaluronic acid
}

\author{
G. S. HARRIS AND J. R. E. FRASER \\ From the University of Melbourne Department of Medicine, The Royal Melbourne Hospital, Victoria, \\ Australia
}

The appearances and nature of mucin complexes have been studied intensively with synovial fluid and similar concentrations of hyaluronic acid, but there is a paucity of information about mucin complexes precipitated from very dilute hyaluronic acid (for example, 2 to $20 \mu \mathrm{g}$. $/ \mathrm{ml}$.), which can probably be attributed to the rarity of natural solutions of this order except in bacterial and cellculture fluids.

Seastone (1943) precipitated turbid complexes as interfacial rings by layering streptococcal culture medium on acidified serum in high salt concentration. Hyaluronic acid was thus measurable in the range 20 to $200 \mu \mathrm{g} . / \mathrm{ml}$, , and as little as $2 \mu \mathrm{g} . / \mathrm{ml}$. could be detected, but the conditions required for accurate measurement (Meyer and Rapport, 1952) are not easily achieved in cell-culture fluids. Mucin clots have been formed in growth medium from synovial and other cultures with a minimum level of 20 to $30 \mu \mathrm{g}$. hyaluronic acid per ml. (Grossfeld, Meyer, and Godman, 1955; Grossfeld, 1961). Mucin clots have also been precipitated from cellculture media by dialysis against acid buffer, but recovery of less than $15 \mu \mathrm{g}$. hyaluronic acid per $\mathrm{ml}$. is incomplete and unpredictable (Hamerman, Todaro, and Green, 1965). Nevertheless, the mucin clot test has been widely used to study the secretion of hyaluronic acid in vitro (see Dingle and Webb, 1965).

The speed and simplicity of the mucin clot test make it very useful in day-to-day observation of synovial cell cultures, even though hyaluronic acid content of the medium is usually less than $20 \mu \mathrm{g} . / \mathrm{ml}$. However, at this level, we have found that the bulk and appearance of mucin clots are greatly influenced by the associated serum independently of the concentration of hyaluronic acid. These findings suggest that the clots might not always contain all the available hyaluronic acid or that there is a consicerable variation in their protein content. Mucin clots from synovial fluid precipitate hyaluronic acid completely in the pH range $2 \cdot 4$ to $4 \cdot 1$, and contain 57 to 80 per cent. protein (Pigman, Hawkins, Gram- ling, Rizvi, and Holley, 1960). The protein content of the clots is said to be influenced by that of the parent fluid (Ropes, Robertson, Rossmeisl, Peabody, and Bauer, 1947; Sundblad, 1950), but the extent of this influence has not been clearly defined.

In this paper the formation and composition of mucin clots from synovial cell-culture medium and similar fluids are considered, partly for comparison with the findings in studies of synovial fluid and partly to evaluate the mucin clot as a measure of hyaluronic acid in cell-culture medium. A basis was also needed for further study of a peculiar inhibitory effect of fresh serum upon mucin complex formation, which will be described separately.

\section{Material and methods}

HYALURONIC ACID Synovial fluid obtained from human knee joints post mortem was filtered through fibreglass and cleared by centrifugation. Hyaluronic acid was concentrated from this fluid as ultrafilter residues (Ogston and Stanier, 1950) using Millipore membrane of $0.45 \mu$ pore-size to ensure selection of highly polymerized material. The residues were dissolved in $0 \cdot 15$ $\mathrm{M} \mathrm{NaCl}$.

HUMAN SERUM was prepared from normal fasting subjects, and treated at $56^{\circ} \mathrm{C}$. for 30 minutes.

GROWTH MEDIA from stock synovial cell cultures (Fraser and McCall, 1965) contained 10 per cent. human serum and 5 per cent. foetal calf serum, both heatinactivated.

REFERENCE STANDARDS were dialysed human serum proteins (courtesy of Dr. C. W. Baird) and glucoronolactone (L. Light and Co.). All other chemicals were of analytical grade.

HYALURONIC ACID* was measured against glucuronolactone standards by a carbazole reaction (Bitter and Muir, 1962) with restricted heating to minimize interference by residual protein (Harris and Fraser, 1969a) PROTEIN* was measured with the method given by Lowry, Rosebrough, Farr, and Randall (1951) for alkaline solutions.

DEVELOPMENT OF MUCIN Clots The parent solutions were either undiluted culture medium, or 10 to 50 per cent. $v / v$ of serum with predetermined amounts of 
hyaluronic acid in $0.15 \mathrm{M} \mathrm{NaCl}$ diluted from the stock solutions. Samples of 1 to $3 \mathrm{ml}$, depending on the anticipated hyaluronic acid content, were placed in $6 \mathrm{ml}$. high-speed centrifuge tubes. Glacial acetic acid was added to 10 per cent. $\mathrm{v} / \mathrm{v}$ and the mixture was then gently shaken to produce a mucin clot. For quantitative studies, methanol was immediately added to 10 per cent. $\mathrm{v} / \mathrm{v}$. Centrifugation at $12,000 \mathrm{G}$. for $10 \mathrm{~min}$. deposited clots as flat films which were washed twice with further centrifugation. For measurement of hyaluronic acid, the deposits were fragmented with a Vortex mixer and thoroughly agitated for 5 to $10 \mathrm{~min}$. with $0.1 \mathrm{ml}$. of a solution containing $5 \mathrm{~g}$. $\mathrm{KOH}$ in 90 per cent. $\mathrm{v} / \mathrm{v}$ of ethanol in water. The residue was separated at $12,000 \mathrm{G}$. for $5 \mathrm{~min}$., dried at $38^{\circ} \mathrm{C}$., and dissolved in an appropriate volume of $0.1 \mathrm{M} \mathrm{NaOH}$. The solutions were then shaken intermittently at room temperature for $2 \mathrm{hrs}$ and subjected to analysis for hexuronic acid and protein. Optical densities in the colorimetric reactions were read against reagent blanks, since no material giving significant readings was precipitated from serum alone.

\section{Results}

\section{DEVELOPMENT OF THE CLOTS}

The several phases of clot formation developed slowly and were more easily seen than in normal synovial fluid. When acetic acid was added, the solution first remained clear but became appreciably viscous. The clot then developed very slowly, but sometimes did not appear at all, whereupon the solution gradually lost its increased viscosity. Gentle shaking, if not delayed, speeded and ensured formation of the clot which then contracted in the usual way. With very small amounts of hyaluronic acid, the clot might subsequently disperse partially or completely if left to stand for an hour or so, but inclusion of 10 per cent. methanol prevented this tendency and gave a tighter, less sticky clot more easily spun down.

Apart from the expected variation with the amount of hyaluronic acid, the size of mucin clots was directly related to the concentration of serum. Thus clots developed in 50 per cent. serum were consistently several times larger than those in 10 per cent. serum (Fig. 1), whether in culture media in which the hyaluronic acid was independently measured by another method (Harris and Fraser, 1969b), or in mixtures of predetermined composition. The smallest detectable clots were merely a few threads from $2 \mu \mathrm{g}$. hyaluronic acid in $1 \mathrm{ml}$. 10 per cent. serum, (i.e. with about $7 \mathrm{mg}$. serum protein).

Hyaluronic acid in foetal calf serum alone gave precipitates of numerous fine but stable threads, a difference which was probably due to the greatly different protein constitution of foetal calf serum (see, for example, Clarris and Fraser, 1967).
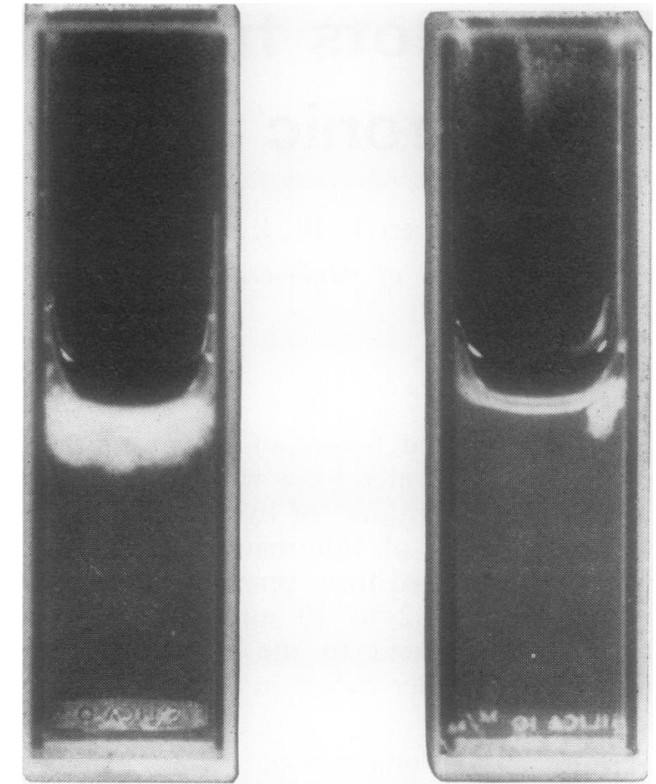

FIG. 1 Mucin clots formed from $75 \mu \mathrm{g}$. hyaluronic acid per $\mathrm{ml}$.

Sample on left: 50 per cent. $\operatorname{serum}(v / v) . ;$

Sample on right: 10 per cent. serum $(v / v$.).

of hyaluronic acid with different amounts of serum (Fig. 2). The pH of the supernatant fluids ranged between $3 \cdot 5$ and $4 \cdot 5$. In each series, one group was washed, drained, and dissolved in $\mathrm{NaOH}$ without further treatment, to permit measurement of the original protein content of the clots. The other group was extracted with ethanolic $\mathrm{KOH}$ before solution

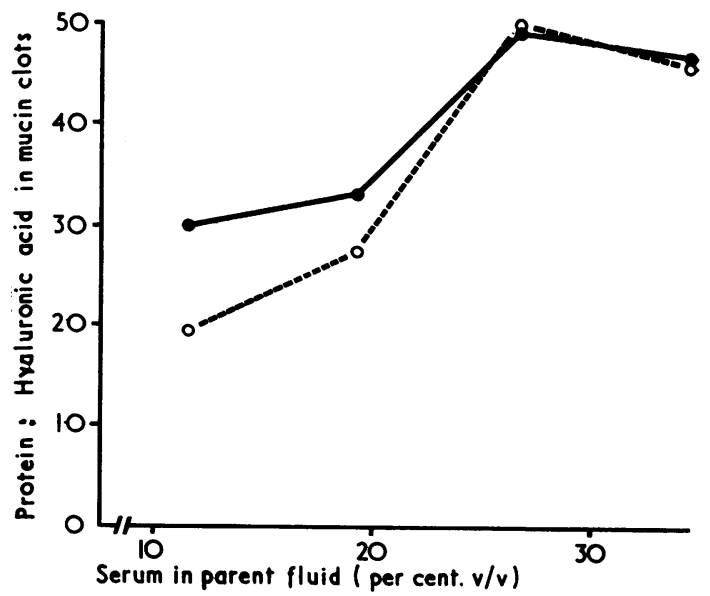

FIG. 2 Composition of mucin clots with increasing serum concentration.

Continuous line: parent fluid $5 \cdot 3 \mu g$. hyaluronic acid per $\mathrm{ml}$.; mean recovery in clots $5.4 \mu \mathrm{g} . ;$ S.D. $0.87 \mu \mathrm{g}$.

Interrupted line: parent fluid $3.4 \mathrm{\mu g}$. hyaluronic acid per $\mathrm{ml}$.; mean recovery in clots $3 \cdot 2 \mu \mathrm{g} . ;$ S.D. 0.77 $\mu \mathrm{g}$. 
in $\mathrm{NaOH}$ for measurement of residual protein and of hyaluronic acid. The recovery of hyaluronic acid was virtually complete and independent of the serum content. The protein content of the clots ranged from 65 to $260 \mu \mathrm{g}$. before, and from 10 to $78 \mu \mathrm{g}$. after extraction. The protein : hyaluronic acid ratios in the clots increased with the serum content.

Clots were also developed from different concentrations of hyaluronic acid in a constant serum concentration of 50 per cent. $\mathrm{v} / \mathrm{v}$ (Table I). The protein : hyaluronic acid ratio in the mucin clots fell progressively as the amount of hyaluronic acid increased.

Table I Composition of mucin clots in relation to amount of hyaluronic acid

\begin{tabular}{|c|c|c|c|}
\hline \multicolumn{2}{|c|}{$\begin{array}{l}\text { Concentration of hyaluronic } \\
\text { acid }(\mu g . / \mathrm{ml} .)\end{array}$} & \multirow{2}{*}{$\begin{array}{l}\text { Protein in } \\
\text { mucin clot } \\
(\mu g .)\end{array}$} & \multirow{2}{*}{$\begin{array}{l}\text { Ratio of pro- } \\
\text { tein: hyaluro- } \\
\text { nic acid in } \\
\text { mucin clot }\end{array}$} \\
\hline Added & $\begin{array}{l}\text { Recovered as } \\
\text { mucin clots* }\end{array}$ & & \\
\hline $\begin{array}{l}13 \cdot 1 \\
28 \cdot 1 \\
58 \cdot 3 \\
86 \cdot 2\end{array}$ & $\begin{array}{l}14 \cdot 0 \\
30 \cdot 0 \\
56 \cdot 7 \\
90 \cdot 3\end{array}$ & $\begin{array}{r}418 \\
795 \\
1,179 \\
1,512\end{array}$ & $\begin{array}{l}32 \\
28 \\
21 \\
18\end{array}$ \\
\hline
\end{tabular}

After extraction with ethanolic KOH (see Methods).

* Calculated from added hyaluronic acid as the better catimate.

Further observations of recovery of hyaluronic acid in mucin clots

Clots were formed from known added amounts of hyaluronic acid and different amounts of serum (Table II). Mean recoveries of hyaluronic acid were complete throughout.

Table II Recovery of hyaluronic acid from different concentrations of serum

\begin{tabular}{|c|c|c|c|c|}
\hline \multirow{2}{*}{$\begin{array}{l}\text { Hyaluronic } \\
\text { acid added } \\
(\mu g . / \mathrm{ml} .)\end{array}$} & \multirow{2}{*}{$\begin{array}{l}\text { Serum } \\
\text { concentration } \\
(\text { per cent. } v / v)\end{array}$} & \multicolumn{3}{|c|}{$\begin{array}{l}\text { Recovery of hyaluronic acid } \\
\text { from mucin clot }(\mu g . / \mathrm{ml} .)\end{array}$} \\
\hline & & Mean & S.D. & Range* \\
\hline $\begin{array}{r}2 \cdot 7 \\
5 \cdot 2 \\
9 \cdot 2 \\
10 \cdot 2 \\
14 \cdot 0\end{array}$ & $\begin{array}{l}10 \\
50 \\
33 \\
50 \\
50\end{array}$ & $\begin{array}{r}2 \cdot 7 \\
5 \cdot 3 \\
9 \cdot 7 \\
10 \cdot 4 \\
14 \cdot 3\end{array}$ & $\begin{array}{l}0.44 \\
0.31 \\
0.55 \\
0.47 \\
0.75\end{array}$ & $\begin{array}{r}2 \cdot 0-3 \cdot 3 \\
4 \cdot 9-5 \cdot 8 \\
9 \cdot 1-10 \cdot 7 \\
9 \cdot 8-11 \cdot 0 \\
13 \cdot 1-15 \cdot 0\end{array}$ \\
\hline
\end{tabular}

${ }^{*} n=6$.

One pool of synovial cell culture medium containing 10 per cent. human and 5 per cent. foetal

Table III Daily variation in recovery of hyaluronic acid from culture medium

\begin{tabular}{|c|c|c|c|}
\hline \multirow[t]{2}{*}{ Day no. } & \multicolumn{3}{|c|}{ Hyaluronic acid ( $\mu g . / m l)}$. \\
\hline & Mean & S.D. & Range* \\
\hline $\begin{array}{l}1 \\
2 \\
3 \\
4\end{array}$ & $\begin{array}{l}4 \cdot 3 \\
4 \cdot 5 \\
3 \cdot 9 \\
4 \cdot 4\end{array}$ & $\begin{array}{l}0.60 \\
1 \cdot 14 \\
0.40 \\
0.65\end{array}$ & $\begin{array}{l}3 \cdot 3-5 \cdot 1 \\
3 \cdot 1-6 \cdot 4 \\
3 \cdot 3-4 \cdot 3 \\
3 \cdot 6-5 \cdot 1\end{array}$ \\
\hline
\end{tabular}

$* n=6$. calf serum was extracted by the mucin clot test on four consecutive days with only minor variations in mean recovery (Table III).

Two separate pools of culture medium were also assayed for hyaluronic acid content by the mucin clot test and by a different method based upon precipitation with cetyltrimethylammonium bormide. As reported elsewhere (Harris and Fraser, 1969b), there was close agreement in the mean recoveries of hyaluronic acid by both methods although the mucin clot test gave a significantly greater variation.

All duplicate estimations of hyaluronic acid recovery as mucin clots were considered in two classes: those in which hyaluronic acid was added to serum and those in which it was recovered from cell culture medium.

The errors of single estimates:

$$
S=\sqrt{\frac{\overline{\Sigma d^{2}}}{2 n}}
$$

(Eränkö and Kihlkerg, 1955) are given in Table IV.

Table IV Estimates of error* in recovery of hyaluronic acid

\begin{tabular}{|c|c|c|}
\hline Source & Range $(\mu g . / \mathrm{ml})$. & $\begin{array}{l}\text { Error of single } \\
\text { estimate }(\mu g . / \mathrm{ml} .)\end{array}$ \\
\hline $\begin{array}{l}\text { Samples with } \\
\text { added hyaluronic } \\
\text { acid } \\
\text { Culture medium }\end{array}$ & $\begin{array}{l}2 \cdot 0-36 \cdot 5 \\
0 \cdot 8-3 \cdot 5\end{array}$ & $\begin{array}{l}0.66 \dagger \\
0.42_{\ddagger}^{\dagger}\end{array}$ \\
\hline
\end{tabular}

*Derived from duplicate $2 \mathrm{ml}$. samples.

†37 pairs.

$\$ 26$ pairs.

\section{Discussion}

Complete recovery of very dilute hyaluronic acid as a mucin clot firstly requires a great excess of serum in the parent fluid, a quick separation of the clot, and, preferably, stabilization of the clot with alcohol. The protein separated in the clot must then be reduced in amount to permit assay of the hyaluronic acid by the modified carbazole reaction. In mucin clots from synovial fluid, this can be done by several chemical means after redissolving the clots, but significant losses of hyaluronic acid from microgram mucin clots invariably occur. Alternatively, one component can be broken down enzymically and the other precipitated, which is a tedious procedure and introduces further error. Treatment with ethanolic $\mathrm{KOH}$, which is similar to one method used by Ropes and others (1947), is much simpler and extracts sufficient protein and also any residual phenol red in mucin clots from culture medium.

Separation of mucin clots with the above precautions can provide a quick measurement of very dilute hyaluronic acid in small samples of cellculture medium, and it is a convenient screening test during experiments. The mucin clot test is much 
more sensitive than previously thought, and is thus suitable for visual assessment of the hyaluronic acid in the range found in these fluids, provided that the serum in each sample is identical in origin and concentration.

There are interesting contrasts between microgram mucin clots and those formed in synovial fluid. A much higher ratio of protein in the parent fluid is necessary to precipitate dilute hyaluronic acid. This can also be shown by diluting synovial fluid to similar low levels of hyaluronic acid, when mucin clots cannot be formed unless more protein is added. If the mucin complex is considered as a colloid coacervate, the extremely disparate ratios of the two components (see discussion by Scott, 1967) may have something to do with the lesser stability of the microgram clots. The several phases of clot formation are also much more distinct with dilute hyaluronic acid. The initial viscous phase, which presumably represents the salt-linkage between hyaluronic acid and protein, can persist unchanged or regress unless the solution is agitated. When the complexes do precipitate, the final phase of clot retraction follows as usual, though there is still a tendency to redispersal. Whether redispersal occurs kefore or after clot formation, the hyaluronic acid cannot be recovered again as a mucin clot, which probably explains the low recoveries from clots formed by prolonged dialysis against acid buffers (Hamerman and others, 1965). The redispersal is also consistent with the findings of Pigman and others (1960), who observed an irreversible drop in the viscosity of slightly diluted synovial fluid in the pH range 3 to 4 , preventable by 6 per cent. ethanol. The breakdown of hyaluronic acid implicit in this change did not impair recovery of the hyaluronic acid in clots of such size, but would certainly do so in the microgram range.

In mucin clots from synovial fluid, protein separates with hyaluronic acid in a four- to sevenfold excess. The much higher protein content of microgram clots might be merely due to entrapped fluid as it is related to the serum content, but nevertheless it probably helps to render a few micrograms of hyaluronic acid visible as a mucin clot. On the other hand, the proportion of protein decreases as the concentration of hyaluronic acid is increased, and it may be that in very low concentrations of hyaluronic acid protein is incorporated into mucin complexes to a greater degree, either in the primary salt-linkage or in a secondary form of bonding, because the later phase of aggregation of mucin is sufficiently delayed by dilution.

Precipitation of dilute hyaluronic acid by conjugation with aliphatic quaternary ammonium compounds is even slower and the precipitates are hypobaric (Harris and Fraser, 1969b), which suggests that these precipitants are also incorporated by some form of secondary bonding beyond the limits of simple ionic equivalence. Thus, although measurement of very dilute hyaluronic acid by the amount of combined cationic polymer is technically possible -for example, with radio-active compounds-it is unlikely that the equivalence found in higher concentrations (Scott, 1960) would apply in such conditions, either with protein or with other precipitants.

\section{Summary}

Visible mucin clots can be precipitated from solutions containing as little as $2 \mu \mathrm{g}$. hyaluronic acid per ml., but only if excess serum proteins are present, equivalent to about 10 per cent. heat-inactivated human serum. Mucin complexes formed in such solutions tend to redisperse, either in the initial stage of gelation after adding acetic acid, or after the formation of a clot. If the clots are stabilized with a small amount of methanol and separated quickly by centrifugation, hyaluronic acid can be recovered quantitatively and measured in such clots. The visible bulk of mucin clots formed with dilute hyaluronic acid is greatly influenced by the serum present. The proportion of protein in the clots is far greater than in clots formed in synovial fluid. It is directly related to the amount of serum, and inversely related to the amount of hyaluronic acid in the parent solution. With these reservations, the mucin clot test can be used as a simple and relatively quick visual or quantitative measure of hyaluronic acid in very dilute solution.

We are grateful to Prof. E. G. L. Bywaters for review of the manuscript. The work was made possible by grants from the Arthritis and Rheumatism Council for Research in Great Britain and the Commonwealth, the Australian Rheumatism Council, and the National Health and Medical Research Council of Australia.

\section{References}

BitTer, T., AND MUIR, H. M. (1962) Analyt. Biochem., 4, 330 (A modified uronic acid carbazole reaction).

Clarris, B. J., AND Fráser, J. R. E. (1967) Aust. J. exp. Biol. med. Sci., 45, 459 (The efforts of homologous and heretologous whole serum upon multiplication of recently-isolated human synovial cells in culture)

Dingle, J. T., AND WebB, M. (1965) In 'Cells and Tissues in Culture. Methods, Biology and Physiology', ed. E. N. Willmer, vol. 1, p. 365. Academic Press, London, New York. ERÄNKö, O., AND KIHLBERG, J. (1955) 'Quantitative Methods in Histology and Microscopic Histochemistry',
p. 23. Karger, Basel. 
Fraser, J. R. E., AND McCall, J. F. (1965) Ann. rheum. Dis., 24, 351 (Culture of synovial cells in vitro).

Grossfeld, H. (1961) J. nat. Cancer Inst., 27, 543 (Production of hyaluronic acid by fibroblasts growing from explants of Walker Tumor ${ }^{256}$ : Production of hyaluronidase by the tumor cells).

- Meyer, K., and Godman, G. (1955) Proc. Soc. exp. Biol. (N.Y.), 88, 31 (Differentiation of fibroblasts in tissue culture as determined by mucopolysaccharide production).

Hamerman, D., Todaro, G. J., and Green, H. (1965) Biochim. biophys. Acta, 101, 343 (The production of hyaluronate by spontaneously established cell lines and viral transformed lines of fibroblastic origin).

HARris, G. S., AND FraSer, J. R. E. (1969a) Analyt. Biochem., 27, 433 (Behavior of serum in the borate modification of the carbazole reaction).

- - (1969b) J. Lab. clin. Med., 74, 527 (Extraction and measurement of glycosaminoglycans in serum and cell culture medium: A system with the use of an aliphatic quaternary ammonium salt).

Lowry, O. H., Rosebrough, N. J., FarR, A. L., AND Randall, R. J. (1951) J. biol. Chem., 193, 265 (Protein measurement with the Folin phenol reagent).

MeYer, K., AND RAPPORT, M. M. (1952) Advanc. Enzymol., 13, 199 (Hyaluronidases).

Ogston, A. G., AND Stanier, J. E. (1950) Biochem. J., 46, 364 (On the state of hyaluronic acid in synovial fluid).

Pigman, W., Hawkins, W., Gramling, E., Rizvi, S., And Holley, H. L. (1960) Arch. Biochem. Biophys., 89, 184 (Factors affecting the viscosity of hyaluronic acid and synovial fluid).

Ropes, M. W., Robertson, W. v.B., Rossmeisl, E. C., Peabody, R. B., ANd Bauer, W. (1947) Acta med. scand., Suppl. 196, p. 700 (Synovial fluid mucin).

ScotT, J. E. (1960) Meth. biochem. Anal., 8, 145 (Aliphatic ammonium salts in the assay of acid polysaccharides from tissues).

- (1968) In 'The Chemical Physiology of Mucopolysaccharides', ed. G. Quintarelli, chap. 12. Little, Brown, Boston.

SEASTONE, C. V. (1943) J. exp. Med., 77, 21 (The occurrence of mucoid polysaccharide in haemolytic streptococci of human origin).

Sundblad, L. (1950) Acta orthop. scand., 20, 105 (The chemistry of synovial fluid with special regard to hyaluronic acid.) 